\title{
DE INSTELLING VAN DE COMMISSIE VOOR DEN HANDEL DER OOST-INDISCHE COMPAGNIE OP CHINA IN 1756.
}

DOOR

\author{
DR. J. DE HULLU.
}

De regeling van het jaar 1734, welke het bestier van den Chinaschen handel aan Gouverneur-Generaal en Raden overdroeg ${ }^{1}$, schijnt aanvankelijk vrijwel te hebben beantwoord aan de verwachting. Een tijdgenoot toch, de Zeeuwsche Bewindhebber Samuel Radermacher, verklaarde in 1756 dat \&de retouren ons» van China "over Batavia toegekomen in den beginne ongelijk meerdere avantagies gaven» dan die uit de jaren, toen de handel derwaarts rechtstreeks door de Vergadering van Zeventien werd gedreven. ${ }^{2} \mathrm{Op}$ het oogenblik echter dat Radermacher deze woorden neerschreef, waren de Zeventien alweer tot het vroegere stelsel teruggekeerd. Uit misnoegen over het wanbeleid, te Batavia in het werk van China gehouden, hadden zij in hun voorjaarsvergadering van 1755 besloten de negotie op dat rijk niet langer over te laten aan Gouverneur-Generaal en Raden maar wederom onder hun eigen beheer te brengen.

De steen was aan het rollen geraakt door de «Bedenkingen over den intrinsieken staat», waarin de Gouverneur-Generaal Mossel in November 1752 voor de Heeren Meesters in Patria de «zorgelijke gesteldheid» van de Compagnie had opengelegd en de vraag op het tapijt gebracht door wat middelen zij uit haar verval kon worden opgericht. De Zeventien beschouwden als een van de voornaamste oorzaken van de kwaal den ontzettend zwaren last, dien alleen het hoofdcomptoir Batavia aan de Compagnie oplegde - een last, die naar hun berekening

1 Zie deze Bijdragen, deel 73 blz. 147.

2 Brief van Radermacher aan den Advocaat der Compagnie Van der Hoop, 20 Febr. 1756.

DI. 79. 
niet minder beliep dan 37 ton gouds per jaar en daar huns inziens niets tegenover stond, dat als equivalent kon gelden. ${ }^{1}$ Men verkeerde wel in het begrip, zoo schreven zij in Maart 1754 aan Mossel, dat, «deze hoofdplaats nog tegenwoordig zoo voordeelig en noodzakelijk was voor het bestaan van den staat van de Maatschappij», dat zij zulk een reusachtige uitgave rechtvaardigde, maar zij zelf stemden met dit gevoelen volstrekt niet in. Immers voor de opvatting als zou shet gezag van de hoofdplaats, benoodigd wezen voor het behoud of de verdediging van de Molukken, bestond geen reden hoegenaamd. Oneindig veel beter toch ware dit doel te bereiken door de thans op Batavia aangehouden zee- en landmacht te verplaatsen naar Ambon en Banda opdat zij, wanneer de nood aan den man kwam, onmiddelijk bij de hand zou zijn, terwijl zij zooals het nu was ingericht van elders te hulp moest worden gezonden en meestentijds slechts "zeer gebrekkelijk, en eerst te laat kon opdagen, nog daargelaten dat zulk een 'secours, dikwijls van Batavia niet verleend kon worden wijl men het daar zelf behoefde ter verdediging tegen de onrustige buren. Ook had men al van oudsher terecht begrepen dat tot dekking van Ambon en Banda en tot "praeservatie van den privatieven handel van de Maatschappij in deszelfs valuabele producten, de naburige Compagniesetablissementen van Makassar en Ternate veel beter waren gelegen. Veel minder nog hing de negotie op Japan van het contzag" der hoofdplaats af "vermits die natie uit geheel andere inzichten met ons handelde?.

En vraagde men hoeveel dat ontzag te beteekenen had voor 's Compagnie's handel op Sumatra, Mossel's eigen bekentenis, dat men dien aan een 'zongenaamde societeit had overgelaten ${ }^{2}$ omdat hij niet eens de kosten goed kon maken van het jaarlijks daarheen gezonden Compagniesschip, gaf op die vraag het antwoord. Nam men daarenboven in aanmerking hoe onze mededingers op al de Westersche comptoiren ${ }^{3}$ een oneindig veel grooter handel dreven dan wij zonder dat zij er.zich den

1 Rescriptie van de Zeventien op Mossel's Bedenkingen, 28 Mart 1754.

- Bedoeld is de Commeroie-Soeiëteit te Padang, die in Augustus 1751 van de Hooge Regeering te Batavia octrooi verkreeg om gedurende drie jaar den handel tussohen Padang en Batavia te mogen drijven, met uitsluiting van anderen.

- De comptoiren bewesten Malakka. 
last van zulk kostbaar etablissement voor getroostten, dan rees er onwillekeurig twijfel op of men zich van een hoofdcomptoir als dat van Batavia geen verkeerde denkbeelden vormde en of er voor den dienst van de Compagnie wel het rechte gebruik van werd gemaakt. Zeker, daar vielen voor het behoud van zulk een hoofdcomptoir wel eenige schoonschijnende redenen aan te voeren en allen, wier particulier belang bij de kostbare huishouding op Batavia profijt vond, zouden begrijpelijkerwijs niet nalaten op de noodzakelijkheid van een "respectabel hoofdetablissement in Indië zeer sterk te urgeeren", vooral omdat dit gelijk het heette gelegenheid bood om de onderhoorige comptoiren van tijd tot tijd met sbrave, eerlijke en kundige» dienaren te voorzien, op hun doen en laten voortdurend toezicht te houden en ze bij het geringste plichtsverzuim op de meest prompte wijze te straffen. Doch wie in dezen een onderzoek mocht instellen, zou bevinden hoe weinig Batavia sinds tal van jaren aan deze vereischten had beantwoord, en tot geen ander besluit kunnen komen dan edat het equivalent voor dit drukkend etablissement na een contributie van zoovele millioenen, op elkander gestapeld om deszelfs splendeur te souteneeren, nog wel te zoeken maar geenszins gevonden was. Men had bijvoorbeeld maar het oog te slaan op de directie van Bengalen, zoo dicht bij Batavia en vlak onder deszelfs bestier en toezicht, gelegen. Welnu, daar hadden de eene directeur voor en de andere na zich sinds tal van jaren schuldig gemaakt aan de “enormste uitstappen ${ }^{1}$ en morserijen ${ }^{2}$, de bezittingen en belangen van de Compagnie als roofgoed behandelend, de inkoopsprijzen van de goederen willekeurig en door de meest geraffineerde practijken opdrijvende, en de uitdrukkelijke orders en reglementen, door de Bewindhebbers op het stuk van den inkoop van lijnwaden en andere artikelen vastgesteld, op de schreeuwendste 'violeerende zonder het minste regard op eed en plicht, om te zwijgen "van 's Compagnie's avancen ${ }^{3}$ op het zilver, dewelke een geheele reeks van jaren verduisterd waren gebleven.. "En (zoo vervolgen zij) beschouwt men verder hoe de Maatschappij onder de Bataviasche directie in China bediend wordt, zoo bewijzen de publieke verkoopingen onzer competiteuren in deze

1 Buitensporigheden.

2 Knoeierijen met ongeoorloofden particulieren handel.

3 Winsten. 
gewesten dat de Nederlandsche Maatschappij op geen 40 à 50 percent, alleen in de verkoopsprijzen, nevens haar bestaan kan. Wij vragen of het voor ons verantwoordelijk en met onzen plicht bestaanbaar kan geoordeeld worden, dat wij nog langer zoowel de directie als de voorzieningen van alle de subalterne etablissementen van de Maatschappij blijven demandeeren en overlaten aan diegenen, die ons van oude tijden her zulke wettige redenen van klachten gegeven en van ons vertrouwen altoos zoo notabel geabuseerd hebben, daar onze competiteuren in haar vaart en handel, ten minste op alle de Westersche comptoiren van Indië, dewelke die van de Nederlandsche Maatschappij zeer verre in waarde surpasseert, ons immers leeren kan hoe weinig men tot het bestier van dien handel van hier het ministerium van een plaats als Batavia van noode heeft, en dat wij het zeer kwalijk begrijpen dat onze wijze van negotieeren voor de Maatschappij een superioriteit boven haar directe vaart produceert. En indien derhalve geen betere en efficacieuser voorzieningen tegens alle de voornoemde uitstappen in 't vervolg komen gedaan te worden, zoo bevinden wij ons immers indispensabel verplicht en genoodzaakt om het bewind en de directie over alle deze buitencomptoiren in onze eigen handen te nemen en alle die plaatsen immediaat en direct van hier met de vereischte opperhoofden en mindere dienaren te voorzien, op wier kundigheid in den handel wij meer staat en voor wier trouwe wij hier te lande meer gerustheid kunnen erlangen, naar het exempel van alle de andere vreemde Maatschappijen, dewelke alle hunne hoofdcomptoiren, in het westelijke gedeelte van Indië gelegen, zelf bestieren en bezorgen ook direct bevaren en met de noodige ministers en andere dienaren voorzien, wier gedrag en administratie onder haar eigen ongen komende door hen zelf onderzocht, overwogen en nagegaan, en niet als bij ons alleenlijk maar als in het verschiet gezien worden., ${ }^{1}$

Wat in het bijzonder den Chinaschen handel aanging merkten de Zeventien nog op, dat zij dien «na eenige preuven v van de directe vaart van uit Nederland op Canton indertijd weer aan het beleid van Gouverneur-Generaal en Raden hadden toevertrouwd, "op de herhaalde en sterke verzekeringen" van dezen «dat de Nederlandsche Maatschappij in dien handel een notoire

1 Rescriptie alsroren. 
superioriteit boven haar competiteuren bezat, wanneer zij maar welberaden genoeg wilde zijn om dezelve geheel en al aan de Indische Directie gedemandeerd te laten vermits, zooals in Uwe Bedenkingen gerepeteerd wordt, 'sCompagnie's schepen te Batavia hun lading vonden, daar andere natiën in China meest met contanten ter markt kwamen. Of wij ons, in onze aanstaande deliberatiën op deze materie, bij zoodanige begrippen zullen kunnen voegen en daarin wezentlijke blijken van de superioriteit in de vaart en handel van de Nederlandsche Maatschappij op China over Batavia boven de directe vaart en handel van haar competiteuren (zullen) komen te ontdekken, is een zaak die wij zoo $\mathrm{min}$ als eenige andere voorgenomen hebben bij deze preliminaire rescriptie finaal te decideeren en, derhalven vooralsnog in het midden gelaten wordende, zoo zullen wij ons voor het tegenwoordige vergenoegeń met alleen aan $U$. E. deze vraag te doen: indien het effective zoodanig met den handel op China gelegen is dat de Nederlandsche Maatschappij daarin een superioriteit boven haar competiteuren bezit, waar het dan vandaan komt dat deze Maatschappij in China hooger prijzen besteedt en daarentegen bij de publieke verkoopingen in deze gewesten op geen 40 à 50 percent nevens haar competiteuren bestaan kan. Deze onverantwoordelijk gecargeerde ${ }^{1}$ inkoopsprijzen in China en de daarop vallende disreputatieuse minderwaarde van 'sCompagnie's retouren in Europa kunnen immers alleen aan twee voorname oorzaken toegeschreven worden, te weten: dat de Nederlandsche Maatschappij in China zoo wel niet bediend wordt als haar competiteuren, of dat zij zoo wel niet kan bediend worden als de gedachte competiteuren omdat de supercarga's van de Nederlandsche Maatschappij aldaar met incourante goederen ter inhandeling en die van hare competiteuren daarentegen met liquide contanten, die allemans gading zijn, ter markt komen. Wij laten de keuze van een van beide deze oorzaken volkomen aan U. E. verkiezing, maar het zij welke van beide U. E. zal goedvinden te accepteeren dan wel alle beide, zoo zal de decisie van den staat der quaestie in faveur van de directe vaart, onder ons eigen bewind en bestier, moeten overslaan. Want indien de Nederlandsche Maatschappij in den handel op China over Batavia zoo getrouw niet bediend wordt of om de geallegeerde redenen zoo wel niet $\mathrm{kan}$ bediend worden als haar competi-

1 D. i. bij de boeken hoog in rekening gebrachte, 
teuren, zoo verseert men immers in Indië in een verkeerd begrip wanneer men zich obstineert om te blijven sustineeren, dat gedachte Nederlandsche Maatschappij een superioriteit bezit, daar die superioriteit zich zoo visibel aan de zijde van haar competiteuren vertoont ${ }^{1}{ }^{1}$

Even ongunstig over de Bataviasche directie van den handel op China oordeelden de Haagsche Besognes der Bewindhebbers van Juli 1754. De gequalificeerde hoofdparticipanten, die hun vergadering hadden bijgewoond, zoo rapporteerden de Besognes aan Heeren Zeventien, "erkenden wel dat diverse zeer voordeelige correctiën zouden kunnen worden gemaakt in het maniement zelfs van de tegenwoordige constitutie van dien handel van Batavia, indien de dienst van de Compagnie deszelfs continuatie op den tegenwoordigen voet kwam te requireeren», maar achtten het den eenvoudigsten weg een antwoord te zoeken op de vraag: "welke goederen, effecten dan wel zilver, best voor den Chinaschen handel conveniëerden, hierdoor verstaande dat diegene, die best conveniëeren of dien naam verdienen, niet alleen de meeste winst moeten afwerpen bij verkoop maar ook de bekwaamste zijn om de differente soorten van retouren van de beste qualiteit en tot de minste prijzen te bemachtigen s, wijl het immers "gebeuren kan dat men op een artikel bij verkoop bijvoorbeeld 10 percent kan winnen maar wederom in den inkoop van het retour 20 percent benadeeld wordt». Om dit punt tot klaarheid te brengen hadden de hoofdparticipanten een carga van uit Batavia naar China afgezonden schepen gebruikt, die te voren nog nooit was nagegaan, teneinde zoodoende het verwijt te ontgaan als zouden zij er met voordacht een hebben "uitgekipt», die hun beter dan andere voor hun beweringen konden dienen. Die carga nu bevatte deels Vaderlandsche of Europeesche deels Indische artikelen. Omtrent die van de eerste soort, bestaande (behalve in eenige Nederlandsche lakenen en ras de marocques ${ }^{2}$ ) in allerlei Engelsche en andere vreemde manufacturen, lood, cochenille en zilver, hadden de hoofdparticipanten "kortelijk aangevoerd», dat immers niemand "zoude willen souteneeren dat deze goederen minder kosten van transport voor de Compagnie en meerder avances in China zullen afwerpen wanneer dezelve, in plaats van direct en immediaat uit Nederland, eerst

1 Rescriptie alsvoren.

2 Een mij onbekende stof. 
naar Batavia gezonden en aldaar, in een pernicieus klimaat gelegen, bedorven en versold zijn geworden (en) ook gesurchargeerd met alle de Bataviasche onkosten, waarvoor de Compagnie zich bij deze expeditie ${ }^{1}$ met $f$ 15081:9:8 gechargeerd vond, behalve de scheepsonkosten (en) maandgelden dewelke ten minste $f 150$ nu bedroegen , of dat zulke via Batavia naar Canton verzonden Europeesche goederen "voordeeliger ingrediënten voor den Chineeschen handel zullen worden dan wanneer men frisscher en in alle opzichten zoogenaamde leverbare goederen direct van hier derwaarts zendt.. Bijgevolg konden naar hun oordeel enkel de Indische artikelen sin consideratie komen, bestaande van de voornoemde equipage in de volgende: 20707 pond nagelen, 9060 pond noten, 2000 pond wilde kaneel, 2.350 .000 pond peper 777.676 pond tin, 23215 pond koper, 60000 pond sappanhout, $612 \frac{1}{2}$ pond kamfer (en) bindrottings. $\mathrm{Na}$ in het algemeen, in overeenstemming met de denkbeelden van "alle commercianten", te hebben vooropgesteld dat zilver voor den inkoop van retouren de voorkeur verdiende boven goederen, hadden de hoofdparticipanten "wijders nog geremarqueerd, vooreerst omtrent de fijne specerijen dat, wanneer men dezelve niet voor 's Compagnie's rekening naar China voerde, dezelfde prijzen daarvoor op Batavia aan de Compagnie waren betaald geworden als de Compagnie in China erlangde, behalve dat het bij vele der rapporten van de Bediendens ${ }^{2}$ bleek dat, wanneer derwaarts gedurende een rond jaar meer dan 40 pikols noten en dezelfde quantiteit nagelen gevoerd werden, de consumptie gesurchargeerd en zij genoodzaakt werden het overige tegens thee, porceleinen of zijdestoffen te baratteeren, ${ }^{3}$ een manier van handel, waarvan de Compagnie altoos de dupe was», terwijl de wilde kaneel, de eenigste soort van kaneel die men kon zeggen dat in China getrokken werd omdat de Chineezen de allerfijnste in hun eigen land vonden, daar zij niet meer dan 3 stuiver van het pond gold «geen object was om en ligne de compte te brengen». Ten opzichte van de peper kon men weliswaar tegenwerpen dat, zoo de fijne specerijen al «geen object» waren, niettemin een hoeveelheid van 2.350 .000 pond, die men op andere tijden wel eens had verhoogd tot 3.000 .000 pond, wel «degelijk van importantie» was en dat dus

1 D.i. van de schepen, van wier carga hier sprake is.

2 Van de Nederlandsche factory te Canton.

3 Ruilen, 
-de Compagnie, daarop winnende van 120 tot 160 percent, zeer wijselijk geageerd had wanneer zij door haar schikkingen zich zulke importante winsten» had verzekerd. Edoch, het was de vraag of deze winst metterdaad wel zoo groot was als zij in de "rendementen» werd opgegeven, en zoo ja (hetgeen echter door de hoofdparticipanten werd ontkend) dan had men te bedenken dat, zooals de Compagnie was geconstitueerd, alle winsten geen reëele winsten waren ja veeleer als wezenlijke «schadens» dienden te worden beschouwd als een nauwkeuriger onderzoek uitwees, dat de Compagnie een veel grooter winst kwam te derven, die haar «door een ander middel van débouché, ten deel zou zijn gevallen. Zulk een behandeling van zaken zou gewisselijk in strijd wezen met cden eersten en eenvoudigsten grondregel van de commercie», dat een verstandig koopman er bestendig op uit behoort te zijn om voor het vertieren van zijn waren die markten op te zoeken, waar hij de meeste winst kon behalen. En de hoofdparticipanten hielden staande dat inderdaad de winst niet zoo groot was als de rendementen vermeldden, vermits «door een tour d'adresse de Indische regeering, om aan haar particuliere oogmerken te voldoen en apparent wetende dat men in Nederland nu en dan maar eens een rendement maar nooit de negotieboeken consuleert, wel op een zeer adroite wijze maar om zeer captieuse redenen de tael in China, in de valuatie, van 71 á 72 stuiver, zooals dezelve naar de hoogste markt gerekend effective maar waardig was, van tijd tot tijd op 88 stuiver verhoogd had, hetwelk circa 23 percent differeerende van de evaluatie der Nederlandsche speciën ook van de voornoemde Bataviasche winsten, om dezelve te realiseeren, moest afgetrokken worden»; om er nog van te zwijgen "van welke ruïne en gevolgen ${ }^{1}$ het voor de Compagnie kwam te zijn, dat men hier onkundig was van deze vreemde Indische arithmetica dat 4 en 5 geen 9 maar enkel 7 produceeren. Ten andere, om de vraag te beslissen "of Canton dan wel de Nederlandsche markt de voordeeligste voor den verkoop van de peper was», behoefde men naar het inzicht van de hoofdparticipanten alleen te onderzoeken shoeveel Hollandsch geld de Chineesche verkoopsprijzen gerendeerd hadden sedert men van den jare 1734 af goedgevonden had om wederom, den handel op China aan

1 Te lezen: „ruineuse gevolgen”? 
de Hooge Regeering te Batavia over te dragen. Bij dat onderzoek nu zou men ontwaren "dat de Chineesche prijzen, gerouleerd hebbende van 8 tael tot 10 tael en 5 (maas) niet meer geproduceerd hadden, al wilde men de tael op den hoogsten prịs van 72 stuiver calculeeren» - hoewel zelfs de GouverneurGeneraal Van Imhoff had erkend, dat 100 tael niet meer dan 73 realen ${ }^{1}$ en bij gevolg één tael maar $71 \frac{67}{75}$ stuiver waard was - "als bijvoorbeeld

$$
\begin{aligned}
& \text { tot } 8 \text { tael à } 9 \text { ducaton }^{2} \\
& , 9, \quad 10 \text {, } 5 \text { (maas) à } 11 \text { ducaton schaars }
\end{aligned}
$$

Hollandsch courant geld». Er was nog meer. Gelijk de Cantonsche Compagniesbedienden zelf erkenden beliep het jaarlijksch debiet van peper van geheel het Chineesche rijk, Tartarije etc. niet meer dan 12 à 15 duizend pikols, en werd deze hoeveelheid «door de Chineesche jonken en andere particuliere avonturiers gewoonlijk alleen aangebracht». Hieruit besloten de hoofdparticipanten, "dat zelfs deze lage verkoopsprijzen van 9 tot 11 ducaton nog niet als reëel maar als chimérique moesten geconsidereerd worden, vermits geen prijzen voor geld maar alleen voor barat waren en dus door de bediendens als arbitrair konden gesteld worden zooals zij kwamen goed te vinden, teneinde dus haar particuliere belangen beter te kunnen doen gelden, even zoo als de Indische regeering de waarde van de tael van $71 \frac{5}{8}$ stuiver, zooals toenmaals gecalculeerd werd, van tijd tot tijd tot op 80 stuiver en in den jare 1743 op 88 stuiver verhoogd had, alleen om de Nederlandsche directie in deszelfs verbeelding van haar chimérique superioriteit door een vertooning van geimagineerde winsten te versterken, zonder te considereeren aan wat gevaren een commerciëerend lichaam door een ignorantie der eerste elementen van de negotie blootgesteld wordt noch welk een getal van millioenen de Compagnie daardoor, alleen maar in een zeker getal van jaren, had komen te missen.. Mogelijk echter geschiedde die afzending van peper uit Batavia naar China in plaats van zilver enkel "omdat er van het laatste niets bij kas was» en de Hooge Indische Regeering het altoos nog beter achtte seen nadeelig fonds dan in het geheel geen fonds

1 Kennelijk een abuis; bedoeld zal zijn: „50 tael niet meer dan 73 realen".

2 De zilveren ducaton gold in Nederland $f 3.15$. 
uit te zenden», nademaal "in het eerste geval de schepen met ballast, en nu nog ten minste met thee etc., hoewel slechter en duurder als van andere Compagnieën, repatriëeren konden». De koper beschouwden de hoofdparticipanten al mede als een suspect artikel» aangezien de Chineezen in den Japanschen koperhandel een veel grooter aandeel bezaten dan de Compagnie, " welke proportie (zeiden zij) men in de Indische correspondentie ${ }^{1}$, dooreengeslagen, als van 16 tot 10 kon calculeeren,, zoodat cwanneer de Compagnie in het bemachtigen van 10000 kisten reüsseerde, de Chineezen voor haar aandeel ten minste 16000 wisten te secureeren, waarvan zij maar een gedeelte in China kunnende debiteeren het overige in andere gedeeltens van Indië moesten uitventen» en bijgevolg geen van de Compagnie behoefden, «behalve nog dat er onder de retroacta's ${ }^{2}$ propositiën van de Heeren Zeventien voorhanden waren om het Japansch koper voor rekening van de Compagnie in China te laten inkoopen wel verre van het van Batavia derwaarts te zendens. En zelfs al ware koper in China een gewild en voordeelig artikel, ook dan nog gaf naar hun gevoelen een debiet van slechts 20 à 30 duizend pond in een rond jaar geen reden om er met 4 à 5 schepen opzettelijk Batavia voor aan te loopen en die aldaar eenige maanden lang te laten vertoeven, aangezien de «incidenteele onkosten van elk te Batavia aan- en inloopend schip de dubbele waarde verslonden van een zoo geringe hoeveelheid koper. Het volgende artikel, de tin, kon ongetwijfeld voor den handel van Batavia op China seen bekwaam ingrediënt, worden geacht, maar de bezwaren in het midden latende, die ook hiertegen vielen in te brengen, stelden de hoofdparticipanten de vraag of de Compagnie het best werd gebaat door die waar te verkoopen aan de op Batavia varende jonken en zoodoende de Chineezen aan te moedigen om aldaar hun inkoopen te komen doen - iets dat van de vroegste tijden af als een zeer nuttige zaak was beschouwd geworden en ook door hen, hoofdparticipanten, als zoodanig werd beschouwd mits men dien jonkenhandel maar aan zulke bepalingen bond, dat hij wel voor Batavia behouden bleef en voordeel droeg doch geen schade toebracht aan de andere takken van 's Compagnie's handel, «dien naar deze landen voornamentlijk daaronder begrepen, - dan

1 In de in Indië opgemaakte brieven en papieren.

2 Stukken uit vroeger tijd betreffende deze aangelegenheid, 
wel of het met het belang der Compagnie beter overeenkwam caan het transport naar en den verkoop in China van de meergedachte Indische producten, voor 's Compagnie's rekening, den voorrang of praeferentie te geven.. Deed men dit laatste dan had men wederom wèl te overwegen of het voor de Compagnie niet profijtelijker zou zijn jaarlijks niet meer dan 2 à 3 honderdduizend pond tin naar China af te schepen dan een hoeveelheid van 7,10 a 15 honderdduizend pond gelijk vele malen was geschied. Verder, ook al was overigens de tin voor den Chinaschen handel geen onvoordeelig artikel, men zou zich zeer bedriegen, meenden de hoofdparticipanten, indien men uit de opgave van het laatst ingekomen rendement, dat een partij tin van 1.447.549 pond voor $f 703161: 8: 8$ was te gelde gemaakt, afleidde dat de verkoopprijs voor de Compagnie "reëel en effective, 48 gulden Hollandsch per 100 pond had bedragen. Want men behoorde in het oog te houden dat de berekening van dit rendement ook al weer steunde op de "Indische valuatie van den ducaton op 78 stuiver of de tael op 88 stuiver , maar dat de verkoopprijs in werkelijkheid de $f 39$ niet te boven ging. Bovendien stond de tin hier te lande hoog in prijs. en zou men, voor den verkoop van dit artikel bij voorkeur de Nederlandsche markt verkiezende, svele andere nutte oogmerken in en omtrent de belading der retourschepen bevorderen, en de afscheping naar het Vaderland vermijden van zulke onnuttige koopmanschappen als suiker, Perzische roode aarde en meer andere van dien aard.

Al die overwegingen, verklaarden de hoofdparticipanten ten slotte, kwamen « volgens hun begrippen zoo sterk te militeeren in faveur van den directen handel uit deze landen naar Chma en vandaar ook wederom à droiture op hier, dat zij zich gemoveerd bevonden hadden, ten minste van harentwege, op de suppressie van 's Compagnie's tegenwoordigen handel van Batavia en de substitutie van de vorige directe vaart en handel van hier te insteeren», met zulke veranderingen wel te verstaan als de gewijzigde tijdsomstandigheden vereischten. Met dit advies van de hoofdparticipanten hadden de Haagsche Besognes, gelijk zij in hun rapport aan de Zeventien mededeelden, zich eenparig vereenigd. In aanmerking nemende evenwel dat het niet voegde ¿op één tijd van hier en van Batavia tegelijk op China te varen ?, gaven zij Heeren Zeventien in bedenken om voorloopig aan Gouverneur-Generaal en Raden de uitvoering af te gelasten van 
de "projecten», bereids voor het jaar 1756 op het stuk van den Chinaschen handel door dezen ontworpen, en om inmiddels en bij voorraad in de aanstaande vergadering van Zeventien "zoodanige commissie» te benoemen als het gewicht en de omvang "der materie kwam te vereischen, teneinde de dienst van de Maatschappij op de beste wijze doenlijk betracht, bevorderd en geëffectueerd " mocht worden ${ }^{1}$.

Alzoo geschiedde; in de vergadering der Zeventien van 11 April 1755 werd besloten dat de Chinasche handel voortaan weder rechtstreeks van uit Nederland zou worden gedreven, onder het beleid eener afzonderlijke commissie die de Zeventien in hun naaste bijeenkomst zouden benoemen, en dat inmiddels dit besluit met de daaruit voortvloeiende orders ter kennis van de Indische regeering zouden worden gebracht. In October daaraanvolgende had de instelling plaats van de bedoelde commissie, gewoonlijk de "Chinasche Commissie" geheeten. "In achting genomen zijnde (zoo leest men in de resolutiën der Zeventien van 14 October 1755) dat (deze) zaak met alle mogelijke secretesse worde behandeld, is goedgevonden en verstaan dat tot het projecteeren en executeeren van al hetgene tot de directe vaart en handel van hier op China zal worden gerequireerd zullen worden gecommitteerd drie heeren uit de Kamer van Amsterdam mitsgaders een heer uit de Kamer van Zeeland benevens een der heeren beëedigde hoofdparticipanten en een der advocaten van de Compagnie; - dat vervolgens gemelde heeren gecommitteerdens zullen worden gequalificeerd, gelijk dezelve worden gequalificeerd mits dezen, omme ten einde voorschreven van de praesidiale Kamer ${ }^{2}$ te verzoeken zoodanig schip of schepen, bemand met de noodige manschap, mitsgaders zoo vele gelden en penningen als zij, heeren commissarissen, oordeelen zullen tot het voeren van den handel benoodigd te hebben, en voorts omme op zoodanig schip of schepen te plaatsen de personen die zij, heeren commissarissen, tot het voeren van den handel dienstig zullen vinden, alsmede dezelve schepen te voorzien met zoodanige goederen en gelden als zij, heeren commissaris-

1 Rapport over het verhandelde in de Haagsche Besognes van Juli 1754, blijkens de resolutie der Zeventien van 11 October 1754 aan dezen op genoemden datum overgelegd.

3 Als praesidiale Kamer der Compagnie fungeerde in het tijdvak 1754-1760 de Kamer Amsterdam. 
sen, zullen oordeelen te behooren, gelijk zij, heeren commissarissen, al verder bij dezen worden gequalificeerd omme aan de overheden van gemelde bodems alsmede aan de bediendens, die tot de voorschreven vaart en handel zullen worden geemployeerd, te geven zoodanige instructie wegens hare te nemene reize en het voeren van den handel en negotie als zij, heeren commissarissen, zullen oordeelen met den dienst van de Compagnie te conveniëeren; - dat, om aan deze gewichtige zake geen hinder of vertraging toe te brengen, de heeren gecomteerdens van de praesidiale Kamer benevens de heer beëedigde hoofdparticipant en advocaat van de Compagnie mits dezen worden verzocht zoo spoedig doenlijk te concipiëeren een plan of project, volgens hetwelk de voorschreven vaart en handel van hier op China zoude kunnen worden ondernomen en gevoerd, en dat, wanneer het voorschreven plan of project zal wezen geformeerd, alsdan door gemelde heeren commissarissen daarvan kennis zal worden gegeven aan dien heer, welken de Kamer van Zeeland zal hebben benoemd tot het waarnemen van de voorschreven commissie, met verzoek dat gemelde heer zich te bekwamer tijd alhier ${ }^{1}$ gelieve te sisteeren omme met de verdere heeren commissarissen het voorschreven plan of project finalijk te arresteeren; - doch dat, indien tegens vermoeden de heer gecommitteerde van de Kamer van Zeeland de voorschreven besognes ten gestelden tijde niet konde assisteeren, de verdere heeren commissarissen zullen zijn gequalificeerd omme het voorschreven plan of project finalijk te arresteeren en ten uitvoer te doen brengen". Overeenkomstig deze schikkingen werden in Januari 1756 voor het lidmaatschap van de Chinasche Commissie aangewezen drie Amsterdamsche bewindhebbers met den Compagniesadvocaat Van der Hoop door de Kamer Amsterdam ${ }^{2}$ en een Zeeuwsche bewindhebber door de Kamer Zeeland ${ }^{3}$, terwijl kort daarop aan dezen uit de beëdigde hoofdparticipanten nog werd toegevoegd de bekende Thomas Hope ${ }^{4}$. Dat de keuze van de hoofdparticipanten op Hope viel lag voor de hand; hij kwam voor den post meer dan iemand anders in aanmerking zoowel om zijn uitgebreide handelskennis als omdat hij het

1 Te Amstordam.

2 Resolutie Kamer Amsterdam 5 Januari 1756.

s Resolutie Kamer Zeeland 22 Januari 1756.

4 Resolutie Kamer Amsterdam 2 Februari 1756. 
voornamelijk was, die tot de voorgenomen reorganisatie van den Chinaschen handel den stoot had gegeven ${ }^{1}$.

Onder al die bedrijven was de brief, waarbij de Zeventien haar van het besluit van 11 April 1755 verwittigden, door de Hooge Indische regeering ontvangen. Met welke gevoelens zij er kennis van zal hebben genomen kan men zich gemakkelijk voorstellen. Niet alleen toch druischte het in tegen haar bestendig streven om zoo vele Compagnieszaken als zij maar kon over Batavia te laten gaan, opdat zij des te meer gunstelingen aan het een of ander postje zoude kunnen helpen ${ }^{2}$, maar het werd haar bovendien medegedeeld in bewoordingen zóó smalend, dat de bittere pil er nog bitterder smaak door verkreeg. Wij hebben, aldus ongeveer schreven de Zeventien, in onze laatstgehouden vergadering met nauwgezetheid en onbevooroordeeld nagegaan wie in den Chinaschen handel de superioriteit bezit: onze Compagnie, die hem van uit Batavia drijft, of wel onze vreemde mededingers, die hem rechtstreeks van uit hun eigen land doen; en wij zijn tot de algemeene overtuiging gekomen dat die superioriteit geenszins, gelijk gewaand wordt ${ }^{3}$, bij onze Compagnie maar metterdaad bij onze vreemde mededingers berust, "waaruit dan noodwendig heeft komen te resulteeren de eenparige en finale resolutie dezer vergadering om de vorige directe vaart uit dezen lande te reëntameeren, en daarmede van hier een aanvang te maken met den jare 1757». En aangezien wij van begrip zijn, «dat het in geenen deele convenabel is om op één en denzelven tijd twee bezendingen naar China, te weten één van dezen lande en een

1 Vgl. Van der Oudermeulen, Iets dat tot voordeel der deelgenooten van de Oost-Indische Compagnie kan strekken (uitgegeven door D. van Hogendorp in zijn Stukken raakende den tegenwoordigen toestand der Bataafsche bezittingen in Oost-Indië en den handel op dezelve, 's Gravenhage en Delft 1801) blz. 114, 115: „de eerste verbetering is ontstaan door het weder in train brengen van de directe vaart op het rijk van China, van waar het eerste schip in 1758 is thuis gekomen. Deze verbetering is de Compagnie voornamentlijk aan den heer Thomas Hope verschuldigd". Ook in de "Aanmerkingswaardige droom ter speculatie aangeteekend behelzende vooreerst de waare oorzaken van 's Compagnie's algemeenen vervallen staat van India enz." door "Oprecht" (opgesteld in 1767 en aangeboden aan Hope) wordt Hope "de bewegende oorzaak" genoemd van de hervatting van den directen handel op China.

Van der Oudermeulen t.a.p.

3 Namelijk door Ulieden. 
andere van Batavia, te doen "zoo gelasten wij u na 1756 geen schepen meer van Batavia op China te laten varen. Wij hadden gaarne deze rechtstreeksche vaart van hier op China een jaar vroeger, en wel in het laatst van 1756, aangevangen, maar aangezien "de projecten bij ulieden ordinair in de maanden Februari en Maart gemaakt worden en de Bataviasche schepen in de maanden Juni en Juli gewoon zijn naar China te vertrekken, zoo hebben wij beter geoordeeld om het zekere voor het onzekere te praefereeren alsmede en ook nog ten andere om aan Ulieden nog een gelegenheid aan de hand te laten teneinde aan ons te doen zien en ondervinden, dat Ulieden waarlijk gedisponeerd zijt om met ons in het zoo noodige redres van de Indische administratie en huishouding te coöpereeren, vermits Ulieden na de ontvangst dezes nog een genoegzamen tijd zullen overhebben om zoodanige voorziening te doen, dat wij in dit uw laatste retour van den jare 1756 gecorrigeerd en verbeterd komen te vinden die disreputatieuse minderwaarde van 's Compagnie's retouren in tegenstelling van die van 's Compagnie's competiteuren, waarover wij zoo lange jaren zonder vrucht gedoleerd hebben, aangezien deze correctie niet ondervindende, na zoo ernstige waarschuwingen van onze zijde, wij noodwendig zullen moeten besluiten dat wij ons niet moeten verbeelden, dat van uwe zijde iets tot redding van de Compagnie zal gecontribueerd worden, ten minste is het daarmede anders gelegen, zooals wij vooralsnog wel willen vertrouwen, zoo kunnen Ulieden nog (bij) deze laatste gelegenheid en bij deze Ulieder laatste bezending naar China aan ons blijken van Ulieder welmeenendheid geven ${ }^{1}$. Niet veel vriendelijker luidt het in in een brief, omstreeks een half jaar later aan GouverneurGeneraal en Raden afgezonden: "wanneer wij acht geven op de klachten, die de directeur en carga's ${ }^{2}$ bij hunne successieve missives hebben gedaan over de slechte constitutie en minderheid ${ }^{3}$ der goederen, welke van tijd tot tijd aan hen zijn toegezonden, ${ }^{4}$ en wij teffens considereeren dat diezelfde Bediendens zoo weinig attentie hebben gegeven op het verkiezen en de verzorging van de goederen, die zij herwaarts hebben afgescheept dat, on-

1 Brief van de Zeventien aan Gouverneur-Generaal en Raden 12 April 1755.

2 Nl. van de Nederlandsche factory te Canton.

3 Geringer gewicht dan de factuur opgeeft, onderwicht.

- Nl. door Gouverneur Generaal en Raden. 
aangezien onze zoo ernstige en menigvuldige recommandatiën en de door gemelde bediendens telkens gedane belofte van beterschap, wij echter al weder het ongenoegen hebben gehad dat de thee, in den jare 1754 alhier aangebracht, is bevonden te zijn zeer slecht en geenszins overeenkomende met de munsters daarvan uitgegeven; dat ook de porceleinen met zoo weinig voorzorge zijn ingepakt geworden, dat dezelve zeer beschadigd zijn geworden», - wanneer wij dat alles overwegen worden wij - meer en meer versterkt in onze genomen resolutie om de vaart en handel op dit rijk, te beginnen met het jaar 1757, onder ons eigen toezicht en opperbewind te nemen., 1

Of men, op het lezen van zulke taal, te Batavia nog eenig succes zal hebben verwacht van het "secreet provisioneel eerbiedig antwoord» 2 , waarmede de Hooge Regeering zich trachtte te verdedigen tegen de beschuldigingen, haar door de Heeren Meesters in Patria toegeworpen? Zooveel is zeker dat dit, trouwens vrij onbeduidende schriftuur, van de Zeventien, wel verre van hun eenmaal genomen besluit aan het wankelen te brengen, slechts een wederwoord uitlokte, ${ }^{3}$ schamperder nog en hautainer van toon dan hun vorige brieven.

Op het tijdstip dat het eprovisioneel eerbiedig antwoord, door de retourschepen in het Vaderland werd aangebracht, in den zomer van 1756, was de inrichting van den Chinaschen handel nog niet door de daartoe benoemde Commissie vastgesteld. $\mathrm{Zij}$ kon dit uit den aard der zaak eerst doen wanneer haar de benoodigde inlichtingen ten dienste stonden, onder andere ook betreffende den omvang dien de buitenlandsche Compagnieën voor het aanstaande jaar aan hunne vaart op China dachten te geven ${ }^{4}$, en zoo liep het aan tot in het laatst van $17 \bar{j} 6$ eer zij aan dat werk de hand sloeg. In haar eerste bijeen.

1 Brief van de Zeventien aan Gouverneur-Generaal en Raden 13 October 1755.

2 Secreet provisioneel eerbiedig antwoord op de rescriptie der Zeventien van Maart 1754", door Gouverneur-Generaal en Raden opgesteld op 15 October 1755.

3 Een niet gedagteekend afschrift van dezen brief der Zeventien bevindt zich onder de Losse. Stukken van de Kamer Amsterdam. Daar er in gesproken wordt van "het jongste jaar 1757" moet de brief van 1758 dateeren.

${ }^{4}$ Vgl. den brief van den Eersten Advocaat der Compagnie Van der Hoop aan zijn medelid in de Chinasche Commissie Samuel Radermacher van 25 Mei 1756: "Over het werk van China zijn tot nog toe geen formeele besognes gehouden omdat verscheidene leden van begrip zijn, dat men de nadere adviezen behoort af te wachten alvorens eenig project met vrucht te kunnen formeeren". (Papieren Radermacher, Algemeen Rijksarchief). 
komst, op 9 November 1756 te Amsterdam gehouden, kwam vóór alles de vraag ter sprake hoeveel schepen, en van welk charter, men naar China uitreeden zou. Oppervlakkig beschouwd leken de tijdsomstandigheden bij uitstek gunstig om onzen handel op dat rijk uit te breiden, want de laatst ontvangen tijdingen hielden in dat de Zwedien, Denen en Emdenaars dit jaar minder en de Franschen in het geheel geen schepen derwaarts gingen zenden. Daar stond echter tegenover dat door den overgrooten aanvoer van Chineesche goederen, welke sinds eenige jaren had plaats gehad, hunne prijzen in Europa aanmerkelijk waren gedaald en er nog groote voorraden van aanwezig waren, alsmede dat in den loop van het aanstaande jaar 1757 weer op zijn minst vier Nederlandsche schepen hier te lande uit Canton stonden aan te komen, en bovendien ook dit nog, dat de Compagnie van wege haar finantiëelen toestand alle mogelijke spaarzaamheid behoorde te betrachten en bijgevolg haar geldmiddelen voornamelijk te gebruiken had voor die takken van haar negotie, waarop zij de meeste profijten kon winnen. Redenen genoeg, naar het eenstemmig oordeel van de Commissie, om voor de aanstaande bezending naar China, "die als een preuve moest worden aangemerkt», slechts twee schepen te bestemmen, van 150 voet ieder ${ }^{1}$, te weten de bodems Sloten en De Spaarzaamheid, welke door de praesidiale Kamer Amsterdam bereids voor dit doel waren "geprojeteerd, en bemand zouden worden, zoo het een als het ander, met ruim 100 koppen, allen zeevarenden, en een tamboer. ${ }^{2}$

De verdere besluiten van de Commissie liepen in de hoofdzaak op dezen zin:

gelijk de scheepsoverheden uitsluitend het bestier zouden hebben te voeren over de schepen en het scheepsvolk, zoo zou het beleid van den handel alleen berusten bij een directeur en vijf carga's die als gage zouden genieten, te weten de Eerste en Tweede carga's $f 150$ ter maand en $1 / 4$ percent van hetgeen de retourlading bij den verkoop hier in Nederland bruto kwam op te brengen, de Derde carga's een maandgeld van $f 80$ benevens $1 / 8$ percent van voormelde opbrengst, en de directeur $f 4000$ mitsgaders $2 \%$ van hetgeen het eene en $5 \%$ van wat het andere schip bruto zou opbrengen;

1 Beide schepen hadden een inhoud van 150 last of 300 ton.

1 Verbaal der Chinasche Commissie 9 November 1756.

DI. 79. 
wijl zoo uit de rapporten van de Bediendens, die sinds eenige jären den Compagnieshandel in China hadden gedreven, als uit andere ingekomen berichten klaar was gebleken dat men om in dit rijk met het meeste voordeel te negotiëeren er met zilver ter markt moest komen, en dat de Compagnie daar te lande geen andere koopmanschappen met eenige noemenswaardige winst kon aanbrengen dan een matige quantiteit tin, lood en eenige weinige specerijen", zou men den handel hoofdzakelijk drijven met contant geld, zullende niettemin naar bevinding van zaken eenige weinige manufacturen, glazen blokken ${ }^{1}$ of andere goederen tot een preuve derwaarts mogen worden verzonden,;

de schepen zouden op de uitreis met lood worden geballast en op de terugreis met zooveel spiauter ${ }^{2}$ als dienstig werd geacht;

om de op de uitreis overblijvende scheepsruimte te benuttigen zouden met de beide bodems van hier naar Batavia worden medegegeven zooveel zeevarenden en militairen als er boven de voor bemanning bestemde honderd man gewoonlijk op schepen van hun grootte werden geplaatst, benevens zoodanige equipageen andere goederen als men te Batavia meest van noode had; de schepen zouden, na die manschappen en goederen te

1 Blijkbaar wordt hier gedoeld op de zoogenaamde glazen moppen, waaromtrent in een memorie van James Turing, medegeassocieerde in de Middelburgsche glasblazerij, in een memorie aan de Kamer Zeeland geezegd wordt dat de Engelsche Compagnieschepen jaarlijks van Londen naar China vervoerden een groote hoeveelheid „best Engelsch kristalglas" of zoogenaamd flint glass gesmolten en opgemaakt als een ordinaire steenen mop, gepakt in kassen van 1000 pond of daaromtrent, en voorzien met ijzeren banden. Dit glas, zegt Turing, werd aan de Chineezen toegezonden deels omdat zij de voor het glasblazen benoodigde specie zelf niet konden maken, deels omdat zij "de ingrediënten, daartoe noodig, niet machtig" waren. Zij smolten die glazen moppen in ovens, vertelt hij verder, en maakten dan daarvan allerlei soorten van glas, die zij tot hun gebruik noodig hadden, „wordende gezegd, dat zij daarvan zeer fraaie en kunstige soorten van glas maken", en aangezien er jaarlijks van dat Engelsche kristalglas meer naar Ohina werd afgezonden dan voor het maken van glas benoodigd was, vermoedde men dat de Chineezen daar nog een ander emplooi voor wisten, dat aan de Europeanen onbekend was. De winst op het artikel liep in China bijzonder hoog voor de Engelsche handelaars, tot 50 percent toe, zoo zegt Turing (Memorie van Turing alsvoren, Papieren Radermacher, Algemeen Rijksarehief).

- Een alliage van ijzer, koper en zink, anderen zeggen: van nikkel, koper en zink, vgl. Description of Canton, $2^{\circ}$ edition, (Canton, 1839) p. 187; en Huysman, La Compagnie d'Ostende (Paris-Bruxeiles, 1902) p. 106. Het werd ook wel tintinago genoemd. 
Batavia te hebben ontladen, aldaar voor den handel in China innemen de nader aan te wijzen hoeveelheden tin enz., terwijl de Hooge Regeering zou worden aangeschreven die ontlading en inscheping zoo spoedig mogelijk te doen geschieden opdat de schepen in hun reis naar China niet werden opgehouden, gelijk deze ook niet langer aan de Kaap zouden mogen vertoeven dan voor hun verversching strikt noodig was;

ingeval zij den handel niet naar genoegen mochten kunnen drijven in Canton, zouden directeur en carga's bevoegd zijn om naar Amoy te varen. Mochten zij op geen van deze beide plaatsen den handel kunnen voeren, zoo hadden zij met de schepen terug te keeren naar Batavia en daar te blijven tot nadere orders uit het Vaderland;

naardien het inkoopen van Chineesch goud door de Compagnie voornamelijk geschiedde ten behoeve van den handel com de West van Indië, 1 en het hiervoor benoodigde kapitaal was begrepen in de 52 ton goud, door de Zeventien op 1 October 1756 tot voldoening aan den jongst uit Indië overgekomen geldeisch ter beschikking gesteld van Gouverneur-Generaal en Raden, besloot de Commissie den Chineeschen goudhandel geheel aan dezen over te laten en hun aan te schrijven, dat zij directeur en carga's bij de aankomst op Batavia zouden voorzien van de daartoe vereischte orders en gelden ${ }^{2}$.

Geen verkoopen noch inkoopen mochten in China worden gedaan, geen contracten voor leveranties gesloten noch leveringen van goederen aanvaard dan in het bijwezen van den directeur en alle carga's, noch zonder dat er een formeele resolutie van was opgemaakt, met aanteekening van de redenen en tevens van het gevoelen der minderheid, ingeval het besluit niet met algemeene stemmen was genomen;

bij staking van stemmen besliste de directeur door het uitbrengen van een dubbele stem;

al wat gedurende hun verblijf in China voorviel op het gebied van den handel en de huishouding moesten de directeur en carga's of bediendens, gelijk zij in de wandeling heetten, te boek stellen in een dagregister, dat in het bijzonder en zoo nauwkeurig mogelijk behoorde te vermelden de aankomst van de vreemde schepen, hunne namen en de namen der gezagvoerders

1 In de landen bewesten Malakka.

2 Verbaal der Chinasche Commissie 9 en 20 November 1756. 
en carga's, hun plaats van herkomst en, zooveel men kon nagaan, wat lading zij hadden ingehad, wat handel door hen was gedreven, wat hun retourvracht geweest was, waarheen $z i j$ waren vertrokken, - in het algemeen gezegd: al wat de Commissie zou kunnen dienen at tot instructie en naricht met relatie tot den verkoop en handel zoowel van Europeesche als van inlandsche Chineesche en andere Indische goederen en waren, dewelke veeltijds tot Canton aangebracht werden, geene hoegenaamd uitgezonderd, ;

de generale negotieboeken, nl. het grootboek, journaal en cassaboek $^{1}$, zouden de Bediendens moeten houden niet alleen «in de gewone Chineesche speciën van taelen, mazen, condrijns, cassi's etc., te weten in dezelve speciën waarin zij met de Chineezen kwamen te handelen en te verrekenen, maar ook in de gewone Chineesche gewichten van pikols, kati's, taelen enz., dit laatste echter met expressie, zoowel bij den verkoop als den inkoop, van het getal van ponden Hollandsch gewicht, waarover zij met de Chineesche handelaars telkens zouden geconveniëerd hebben". En om aan deze order des te beter en met te minder omslag te kunnen voldoen "zouden zij de stukken van achten in die boeken moeten innemen, ieder zak van eenhonderd mark netto gewicht (zooals dezelve effectivelijk waren inhoudende) tot een getal van 913 stukken van achten, en deze wederom tot 74 Chineesche condrijnen voor ieder stuk van achten gerekend, zooals dezelve in het generaal in den handel werden aangenomen. En dit onaangezien het mocht gebeuren dat zij in betaling van goud, ruwe zijde of anderszins hierin niet konden komen te reüsseeren", vermits de Commissie verlangde, dat alsdan "de mindere uitgave van de stukken van achten als tot 74 condrijns het stuk, op de rekening van winst en verlies gebracht en in die rekening afgeschreven werd»;

schoon de stuwage van de retourlading voornamelijk de taak was der scheepsoverheden, legde de Commissie niettemin ook aan de Bediendens de verplichting op om bij dit werk hun medewerking te verleenen. Geschillen, daarover tusschen hen en de scheepsoverheden opkomende, zouden aan het oordeel worden onderworpen van den Breeden Raad of bij diens ont-

1 Een vierde boek, het zoogenaamde „guastosboekje”, bevatte de dagelijksche kleine uitgaven. 
stentenis van den Vollen Scheepsraad ${ }^{1}$, en hetgeen die goedvond zou men stipt moeten nakomen, welverstaande dat wie met die beslissing niet instemde van de redenen voor zijn afwijkend gevoelen aanteekening mocht vorderen, opdat de Commissie daar na den terugkeer der schepen haar gedachten over kon laten gaan, czijnde het niet buiten reden (zegt de Commissie) dat wij van dit poinct der stuwage dubbele mentie maken ${ }^{2}$, vermits wij het bij ondervinding hebben dat, naarmate de supercarga's zich daaraan min of meer hebben laten gelegen liggen en aan boord gevaren zijn om daarvan inspectie te nemen, daarin beter gereüsseerd geworden is 》. En opdat het haar blijken mocht of dit was geschied en, zoo ja, wanneer, alsook of het wel of kwalijk gedaan was, hadden de Bediendens hiervan in hun registers en rapporten melding te doen, waardoor de Commissie meteen des te beter zou kunnen zien hoe en door wien dit gedeelte van 's Compagnie's dienst was waargenomen;

voor de bewaring van de naar China mede te nemen goederen en contanten zouden, zoolang zij niet door hen aan de Bediendens waren afgegeven, de schippers aansprakelijk zijn, daarna zouden zij ter verantwoording van de Bediendens staan, die ieder een sleutel onder zich zouden hebben van de geldkisten, welke men stuk voor stuk van even zooveel differente sloten zou voorzien als er Bediendens waren, zoodat er nooit iets uit kon worden genomen tenzij zij er al te zamen bij tegenwoordig waren ${ }^{3}$;

eindelijk waren - om de minder belangrijke voorschriften achter wege te laten - de Bediendens gehouden om in een ampele

1 De Breede Raad, aldus bepaalde de Commissie in de door haar vastgestelde Generale instructie voor de Bediendens en Scheepsoverheden, zou bestaan uit den directeur en de carga's, de beide schippers en opperstuurlieden en den onderstuurman van het schip, dat de vlag voerde; de Volle Scheepsraad: op het schip, waarop de directeur overvoer, uit den directeur en de op hetzelfde schip aanwezige carga's, den schipper, den opper- en onderstuurman en den hoogbootsman; op het andere schip uit de daarop overvarende carga's, den schipper, den opper- en onderstuurman en den hoogbootsman.

3 Nl. in deze speciaal voor directeur en carga's bestemde instructio zoowel als in die, welke tegelijkertijd aan de scheepsoverheden werd gegeven.

s Wederkeerig werden in de Generale instructie voor de Bediendens en Scheepsoverheden de laatsten verantwoordelijk gesteld voor de bewaring van de retourgoederen van het oogenblik af dat zij aan boord waren gebraoht. 
memorie tot naricht van hun naaste opvolgers te vermelden den toestand der factory, haar meubilair en de voorwaarden, waarop zij was ingehuurd, mitsgaders hun wedervaringen in den handel, de kooplieden met wie zij hadden gecontracteerd voor leveranties, de door hen verkochte en ingekochte goederen, de daarvoor bestede in- en verkoopsprijzen, en wat dies meer zij $^{1}$.

Het fonds voor den handel bepaalde de Commissie voor beide schepen te samen op $f 1.200 .000$ aan baar zilver ${ }^{2}$ en een partij lood, die tegelijkertijd voor ballast moest dienen. ${ }^{3}$ Te Batavia zou hier door Gouverneur-Generaal nog worden bijgevoegd 400.000 pond tin, 5000 pond "vette» muskaatnoten, 5000 pond kruidnagelen en 100.000 pond sappanhout voor garneering. ${ }^{4}$ De uit China mede te brengen retourgoederen moesten bestaan in thee, ruwe zijde, zijdestoffen, porcelein, radix China, radix galinga, rhabarber, curcuma, sago, steranijs, kamfer, aloe, gommegutte en spiauter. ${ }^{5}$ Daar De Spaarzaamheid door onverwacht ingevallen vorst zoolang werd opgehouden tot het seizoen was verloopen ${ }^{6}$, heeft ten slotte enkel het schip Sloten de reis aanvaard. Den 8 December 1756 van Texel's reede uitgezeild, arriveerde het op 6 Juni 1757 te Batavia. Nadat het aldaar de voor den Indischen dienst medegenomen manschappen en goederen had ontscheept en zijn aanvullende lading van tin, specerijen en sappanhout ingenomen, zette het op 22 Juni de reis naar China voort waar het op $31 \mathrm{Juli} 1757$ ter reede van Wampoo nabij Canton het anker uitwierp en liggen bleef tot op den 21 Januari 1758, toen het de terugreis aannam naar het Vaderland, waar het op 6 September daaraanvolgende binnenviel met een lading van 713.459 pond thee, 4936 stuks zijde-

1 Particuliere instructie voor directeur en carga's 6 December 1756.

3 Dit kapitaal werd gefourneerd door de Kamer Amsterdam, Verbaal der Commissie 22 November 1756.

s Blijkens den eisch van retouren 6 December 1756, en Verbaal der Commissie 9 November 1756.

4 Brief van de Commissie aan Gouverneur-Generaal en Raden 1 December 1756. - Garneering $=$ bekleeding van het scheepsruim om alzoo een glad boord te verkrijgen tot beter, vaster opstuwing van de lading.

5 Eisch van retouren 6 December 1756. De radix China was de als medicijn in China en Indië gebruikte wortel van een plant, de radix galinga een drogerij, die veel als geneesmiddel maar ook bij het brouwen van bier werd gebruikt, zie Linschoten's Itinerario, ed. Kern II blz. 41, Hirth, Chinesische Studien, S. 87, 89.

6 Verbaal der Commissie 8 Uctober 1757. 
stoffen ${ }^{1} 2000$ stuks Nankingsche linnens, 6366 pond ruwe zijde, 10163 pond radix China, 5079 pond radix galinga, 3137 pond rhabarber, 10072 pond curcuma, 1451 pond sago, 2553 pond gommegutte, 61751 pond spiauter en een aanzienlijke partij porceleinen. ${ }^{2}$

1 In den beantwoorden eisch van retouren, door de carga's opgesteld, wordt de thee als volgt gespecificeerd: souchon 36361, congo 129082, songlo 59563, heysan 6634, bing 3602 en boei 478217 pond; de zijdestoffen bestonden, gelijk daar wordt opgegeven, in het volgende getal stukken nl. 300 één- en 100 tweekleurige meubeldamasten, 850 eenkleurige poisesdamasten voor kleeding, 100 eenkleurige gebloemde poisesdamasten, 150 tweekleurige gebloemde dito, 100 gestreepte en gebloemde damasten, 150 goshesdamasten, 100 effen satijnen, 50 effen satijnen met bouquetten, 50 gestreepte satijnen, 100 gestreepte en met bouquetten op de strepen gestikte satijnen, 100 gestreepte en met rankwerk en bloemen alleen op de witte strepen gestikte satijnen, 100 chagrijnen, 50 diemitjes, 50 effen pourdesoyen, 24 gebloemde pourdesoyen, 300 effen gorgorons, 50 gorgorons met satijne strepen, 50 gorgorons à quadrile, 50 gorgorons met geruite satijne strepen en kleur op kleur, 150 effen vierdraads rolarmozijnen, 100 gestreepte vierdraads rolarmozijnen, 650 effen zesdraads rolarmozijnen, 100 weerschijn zesdraads rolarmozijnen, 100 gestreepte zesdraads rolarmozijnen, 100 effen lustrings, 200 effen aohtdraads peking of rolarmozijnen, 50 achtdraads rolarmozijnen met gestikte gekleurde bouquetten, 50 geschilderde zesdraads rolarmozijnen, 50 geschilderde lustrings, 50 geschilderde en met goud en zilver afgezette lustrings, 50 geschilderde satijnen met goud en zilver, 50 lampassen, 150 Chineesche neusdoeken, kleine en groote soort, met ruiten, 50 Chineesche satijne gekeperde neusdoeken, 100 zijden grisetjes, 50 Nanking silk en 50 gestreepte satijnen met heel smalle streepjes, alsmede nog 12 meubeldamasten.

2 De voorraad porcelein bestond volgens den bean woorden eisch van retouren in: 134 stellen van vijven, 2073 paar koffiehuiskoppen met schotels, 2520 stuks koppen alleen", 11933 paar Hollandsch groot dubbel koffiegoed, 24958 paar groot Hollandsch thee- of enkel koffiegoed, 19538 paar Hollandsch theegoed van matige grootte, 19471 paar klein Hollandsch theegoed, 12015 één pints spoelkommen, 1574 chocolaadkoppen met ooren en zonder schoteltjes, 100 theeserviezen, 18955 enkele en 2185 dubbele tafelborden, 4943 twijfelaarstafelborden, 507 schaaltjes, 10802 halvepints kommen, 100 serviezen tafelgoed en 1675 paar Fransch koffiegoed. 